\title{
A comparative study of the allelopathic effects of Albizia lebbeck L. and Ficus virens on growth and germination of Brassica campestris $\mathbf{L}$.
}

\author{
Shah Khalid ${ }^{1 *}$, Ujala Ibrahim ${ }^{1}$, Sadaf Riaz ${ }^{1}$, Maryam Naseem ${ }^{1}$, Marya \\ Sajjad $^{1}$, Wisal Muhammad Khan ${ }^{1}$, Rukhsana Kausar ${ }^{2}$ and Syed Inzimam \\ Ul Haq ${ }^{1}$ \\ 1. Department of Botany, Islamia College Peshawar, KPK-Pakistan \\ 2. Department of Environmental Science, International Islamic University Islamabad-Pakistan \\ *Corresponding author's email: shahkhalid@icp.edu.pk \\ Citation \\ Shah Khalid, Ujala Ibrahim, Sadaf Riaz, Maryam Naseem, Marya Sajjad, Wisal Muhammad Khan, Rukhsana \\ Kausar and Syed Inzimam U1 Haq. A comparative study of the allelopathic effects of Albizia lebbeck L. and Ficus \\ virens on growth and germination of Brassica campestris L. Pure and Applied Biology. Vol. 10, Issue 2, pp368- \\ 377. http://dx.doi.org/10.19045/bspab.2021.100040
}

\begin{tabular}{llll}
\hline \hline Received: 20/07/2020 & Revised: 26/09/2020 & Accepted: 29/09/2020 & Online First: 30/09/2020 \\
\hline \hline
\end{tabular}

\section{Abstract}

Aqueous extract of Albizia lebbeck L. and Ficus virens were studied for their effect on growth (Radicle and plumule length) and seed germination of Brassica campestris. Plant material (leaves) were collected from $F$. Virens and A. lebbeck tree in 5, 10 and $15 \mathrm{~g}$ weight, powdered and was soaked separately in 100 $\mathrm{ml}$ of distilled water. Prepared materials were filtered after 24 hours of soaking time. These exudates were applied to $B$. Campestris seeds to investigate its allelopathic (positive or detrimental) impact on radicle and plumule length and germination percentage, after 24, 48 and 72 hours of incubation period at $26^{\circ} \mathrm{C}$. With increase in extract concentration from 5 to $15 \mathrm{~g}$, a gradual decrease in growth of $B$. campestris occurred. Mean values for percent germination showed that both fresh and dry leaves extract have negative impact on B. campestris. Dry leaves extract obtained from A. lebbeck and F. virens have more inhibitory effect on germination percentage (82\%) at 72 hours than fresh leaves extract $(91 \%)$ with same soaking time as compared to control (100\%). Plumule is found more affected than radicle for both $A$. lebbeck and $F$. virens. Dry leaves extract of $F$. virens was found more inhibitory for radicle length $(0.97 \mathrm{~cm})$ than $A$. lebbeck $(1.20 \mathrm{ccm})$ as compared to control $(4.38 \mathrm{~cm})$ while fresh leaves extract of $F$. virens were found less inhibitory $(1.41 \mathrm{~cm})$ for radicle than A. lebbeck $(1.02 \mathrm{~cm})$, when compared to control $(4.38 \mathrm{~cm})$. Moreover, fresh extract of $A$. lebbeck were observed more inhibitory $(0.41 \mathrm{~cm})$ for plumule length in comparison with $F$. virens $(0.80 \mathrm{~cm})$, while for dry extract $F$. Virens were found more inhibitory $(0.79 \mathrm{~cm})$ on test species than A. lebbeck $(1.27 \mathrm{~cm})$. Result of the study revealed that radicle was more affected negatively by A. lebbeck than $F$. virens while plumule was more inhibited by Ficus than Albizia. However inhibitory effect of both Albizia and Ficus was same on germination percentage of Brassica Campestris, at 72 hours of soaking time. Overall., A. lebbeck was observed more inhibitory than $F$. Virens on test species. The result suggested that $F$. virens and A. lebbeck have overall negative effect on Brassica campestris, reducing germination percentage and seedling growth of test species.

Keywords: Allelopathy; Albizzia lebbeck; Ficus virens; Brassica campestris; Extract 


\section{Introduction}

Any process involving secondary metabolites produced by fungi, bacteria, algae and plants that influence the development and growth of any biological system is termed as Allelopathy [1]. "The process of inhibition of one plant or (other organisms) by another, due to the release of chemicals into the environment, acting as germination and growth stimulators or inhibitors". It is the characteristic feature of certain fungi, algae, bacteria, coral and certain plants. The biochemicals that are produced by plants that effect the germination and various vital processes of other plants are called Allelochemicals.". These Allelochemicals are a subset of secondary metabolites [2] which are not needed for metabolism (reproduction, development and growth) of the allelopathic organisms. Allelopathic chemicals are contributed to soil and environment by volatilization leaching, decomposition of plant residues, and root exudation [3]. Rice [4] classified allelochemicals into fifteen classes, Straight chain alcohols, Aliphatic aldehydes and ketones, Long-chain fatty acids, Simple unsaturated ketones Naphthoquinones, Anthraquinones and complex quinines, Terpenoids and Steroids, Simple Phenols, Benzoic acids and their derivatives, Cinnamic acid and derivatives, Coumarins, Flavonoids, Tannins, Amino acids and polypeptides, Alkaloids and Cyanohydrins, Sulfides and Mustard oil glycosides, Purines and Nucleosides, Miscellaneous, Simple water soluble organic acids. Allelopathy is actually the direct or indirect beneficial or harmful effect of one plant, microorganism or fungus on another by production of allelochemicals. Sometimes the receiver species is referred as "indictor" because it indicates the allelopathic interaction [5]. Allelopathic substances are found in all the generative and vegetative organ of plants
[4]. Allelopathy influences the forestation, succession, forest regeneration, and the metabolites of woody plants, affect the pattern of understory species. Species that are considered to have high percentage of allelopathic effect are Alien species [6]. Ficus virens is a tree belonging to the group of trees called Strangler figs, this is because its seeds can germinate on other trees, grow to strangle and eventually kill the host tree. The Ficus virens has become famous as an avenue tree in New Delhi and around the cities of Noida. It is a very massive tree, in which sometime the size of the crown can exceed the height of the trees. The most massive and oldest Pilkhan trees can be seen inside the complex of Humayun's tomb in Delhi. Young leaves and young shoots are cooked or raw used. They are sometime used in the preparations of curries $[7,8]$. The fruits of figs are edible. Birds, bears and tortoise has been observed feeding on the Ficus virens fruits. A bark decoction is used as a gargle in salivation and wash of ulcers [9]. The wood including the aerial root is used locally in tool making. The wood is used for fuel. The wood and roots are used locally in light constructions [10]. The latex of Ficus virens is used for water proofing and caulking boat. The light colored wood is porous and soft [11]. Leaves are acuminate, alternate, distichous, simple, entire, lanceolate, elliptic or Ovate-elliptic to Ovate oblong. The flower is an axillary, paired, fig, cream colored, globose and thick walled. Ficus produces three types of flowers; male flower, a long-styled female flower, shortstyled female flower (often called gall flower). Branches have few to many aerial roots. Aerial roots are one of the most unique and wonderful feature of figs [12]. Albizia lebbeck L. is large, erect, fast growing, unarmed deciduous tree, having spreading umbrella shaped crown of thin foliage finely fissured, graying brown bark 
and having mimosoid legume. Tree is planted as a shade tree in coffee and tea plantations to suppress weed growth, to reduce soil desiccation and to protect plants from rain storms and hail. Albizzia lebbeck is a great nitrogen fixer, also it produces wood and provide fodder for livestock [13]. Albizzia lebbeck (L) is found in deciduous forests in tropical and sub-tropical countries of Asia, such as Cambodia, Indonesia, Vietnam, Laos Malaysia, Africa, India and is also found in Australia. This tree can tolerate acidity, alkalinity, water logged soils, sodic, drought, lateritic sites, heavy and eroded soils $[14,15]$. Albizzia lebbeck contain the following compounds such as Tannins, Glycosides, Flavonoids, Carbohydrates, Alkaloids Proteins and Amino Acids. Through methanolic successive extracts, tannins, saponins, and flavonoid alkaloids were also reported from the plant [16]. Brassica is the genus of plants in the mustard family (Brassicaceae). The members of the genus are informally known as Cruciferous vegetables, Cabbages, or mustard plants. Sometimes the crops of this genus are called cole cropsderived from latin caulis, denoting the stem or stalk of a plant. Brassica campestris has a particular varieties of oil seed known as canola but usually it has some related species Brassica napus (rap seed) and Brassica juncea (mustard greens and mizuna). Brassica campestris is cultivated for oil production [17].

\section{Materials and Methods}

\section{Collection, drying, crushing and soaking} of plant material

The leaves of the Ficus virens and Albizzia lebbeck tree were collected and washed properly with distilled water. Half of the leaves were allowed to dry in a room and half were chopped fresh using mortar and pestle. Dried leaves were grinded in a food processor to obtain the powder for the extraction purpose.

\section{Processing of fresh and dried leaves}

Solution was prepared from fresh leaves (chopped) in sterilized beakers using different concentrations i.e. 5,10 and $15 \mathrm{~g}$ in $100 \mathrm{ml}$ of distilled water. Similarly, solution was prepared from dried leaves powder in sterilized beakers using different concentrations i.e. 5, 10 and $15 \mathrm{~g}$ in $100 \mathrm{ml}$ of distilled water. All the solutions were kept undisturbed for 24 hours at room temperature in the laboratory of ICP.

\section{Preparation of fresh and dried leaves extract}

All the solutions were filtered, and filtrate were obtained after 24 hours to obtain the respective extracts. Hence aqueous extract of fresh and dry leaves with three concentrations that is $5 \%, 10 \%$ and $15 \%$ w/v were prepared. Extract were collected and stored as stock solution in refrigerator. Overall, twelve extracts were prepared for its use in germination experiment.

\section{Sterilized equipment's and usage of standard filter paper}

Petri dishes, Filter paper, Beakers, Incubator, Refrigerator, stirrer, Digital balance, Funnels, Titration flasks, Iron stand, and Mortar and pestle were used, and all these equipment's were sterilized at 160C for few hours. Whatman.1 filter paper and cotton were used as the seed beds in the experiment.

\section{Test species}

B. campestris was used as test species to check the allelopathic potential of Ficus virens and Albizzia lebbeck (fresh+ dry leaves extract) on it. All the petri dishes that were to be used for the experiment were provided with double folded filter paper and thin layer of cotton beneath. 5 seeds of $B$. campestris were put in each petri dish and was soaked with the respective extracts. Different concentrations of leaves extract were provided after each 24th hours to the petri dishes having seeds placed at equal distance. A control series of 3 sterilized 
petri dishes, soaked double folded filter paper with distilled water was also taken. The petri dishes were placed in an incubator at 24 degree centigrade. After three days of incubation period (72hours), germination percentage, radicle length and plumule length were recorded.

\section{Standard method of Measuring data}

Readings from the Petri dishes was taken after 72 hours of incubation period in the incubator, the seeds that germinated were counted in each Petri dish. With the help of scale, the plumule and the radicle length of the germinated seeds were measured in centimeters. Based on recorded data, mean values were derived. Germination percentage of the Brassica Campestris seeds were recorded by following the method of Scot [18].

$($ Germination Percent $=$ no of germinated seeds / total no of seeds x 100

\section{Results and Discussion}

Inhibition was observed in case of germination percentage in Brassica campestris seeds in all cases that is when both fresh and dry leaves extract of Albizzia lebbeck and Fiscus virens were applied separately.

Effect of 24, 48 and 72 hours of fresh and dry leaves extract of Albizia lebbeck on germination percentage of Brassica campestris seeds

Mean values for different soaking duration shows that highest germination percentage (91\%) of Brassica Campestris seeds is found in 72 hrs of soaking duration when fresh leaves extract were applied and $82 \%$ when dry leaves extract were applied, followed by $(55 \%)$ at $48 \mathrm{hrs}$ and $(36 \%$ and $27 \%$ ) at 24 hrs by using fresh and dry leaves extract. Moreover, extract with all different concentrations $(5 \mathrm{~g}, 10 \mathrm{~g}$ and $15 \mathrm{~g})$ were found to have inhibitory effect on test species that have decreased germination percentage when compared to control $(100 \%) .5 \mathrm{~g}$, and $15 \mathrm{~g}$ (dry leaves) reduced germination percentage to $(73.3 \%)$ while (5g and $10 \mathrm{~g}$ ) fresh leaves have inhibited Radicle length to $87 \%$ at 72 hours when compared to control. Dry leaves extract affected germination more than fresh leaves extract. However, in all the three treatments, varied values of inhibition were found at different soaking time (Table 1; Fig. 1).

Effect of 24, 48 and 72 hours of fresh and dry leaves extract of Ficus virens on germination percentage of Brassica campestris seeds

According to mean values, percent germination is observed for dry and fresh leaves extract of Ficus virens which reduced percent germination of test species to $91 \%$ and $82 \%$ at 72 hours, followed by $55 \%$ at 48 hours and 27 and $36 \%$ at 24hours of soaking duration. Moreover Table 1 showed that in $5 \mathrm{~g}, 10 \mathrm{~g}$ and $15 \mathrm{~g}$ treatment, Ficus virens leaves extract, percent germination was decreased as compared to control (100\%). In (5g, 10g and 15g) treatments, $5 \mathrm{~g}$ and $15 \mathrm{~g}$ (dry leaves) reduced germination percentage to (73.3\%). However, $5 \mathrm{~g}$ and $10 \mathrm{~g}$ fresh leaves also have the potential to inhibit seed germination to $87 \%$ at 72 hours when compared to control (100\%). At 24hours, 15gdry and fresh leaves extract reduced germination percentage to $(23 \%)$ and $(35 \%)$ followed by $10 \mathrm{~g}$ and $5 \mathrm{~g}$, reducing germination percentage to $(23 \%, 37 \%)$ and $(35 \%, 37 \%)$ respectively. Dry leaves extract affected germination more than fresh leaves extract just like Albizia lebbeck. However in all the three treatments, varied values of inhibition were found (Table 1; Fig. 1). Barkatullah [19], Hussain [20], Samreen [21] have been reported that aqueous extract of leaves of Diospyros kaki L. reduced germination percentage of Brassica campestris which greatly support the present findings. Antony [22] also concluded that effect of aqueous extract of leaves of the edible plant 
and Flourita is inhibitory on seed germination of B. campestris. Same result was also reported by Maharajan [23] that seed germination was greatly inhibited by Parthenium hysterophorus leaves extract.

Table 1. Effect of 24, 48- and 72-hours soaking duration extract of Ficus virens and Albizzia lebbeck at $5 \mathrm{~g}, 10 \mathrm{~g}$ and $15 \mathrm{~g}$ fresh and dry leaves on Germination percentage of Brassica campestris $L$. FLE = Fresh leaves extract, DLE = Dry leaves extract

\begin{tabular}{|c|c|c|c|c|c|c|c|c|c|c|c|c|}
\hline Species & \multicolumn{4}{|c|}{ Ficus virens } & \multicolumn{6}{c|}{ Albizzia lebbeck } \\
\hline $\begin{array}{c}\text { Incubation } \\
\text { period }\end{array}$ & \multicolumn{2}{|c|}{$\mathbf{2 4 h r}$} & \multicolumn{2}{|c|}{$\mathbf{4 8 h r}$} & \multicolumn{2}{|c|}{$\mathbf{7 2 h r}$} & \multicolumn{2}{|c|}{$\mathbf{2 4 h r}$} & \multicolumn{2}{|c|}{$\mathbf{4 8 h r}$} & \multicolumn{2}{c|}{$\mathbf{7 2 h r}$} \\
\hline Treatments & FLE & DLE & FLE & DLE & FLE & DLE & FLE & DLE & FLE & DLE & FLE & DLE \\
\hline Control & 98 & 98 & 100 & 100 & 100 & 100 & 98 & 98 & 100 & 100 & 100 & 100 \\
\hline $5 \mathrm{~g}$ & 37 & 23 & 50 & 50 & 87 & 73 & 37 & 23 & 50 & 50 & 87 & 73.3 \\
\hline $10 \mathrm{~g}$ & 37 & 35 & 50 & 65 & 87 & 100 & 37 & 35 & 50 & 65 & 87 & 100 \\
\hline $15 \mathrm{~g}$ & 35 & 23 & 65 & 50 & 100 & 73 & 35 & 23 & 66 & 51 & 100 & 73.3 \\
\hline Mean & 36 & 27 & 55 & 55 & 91 & 82 & 36 & 27 & 55 & 55 & 91 & 82 \\
\hline
\end{tabular}

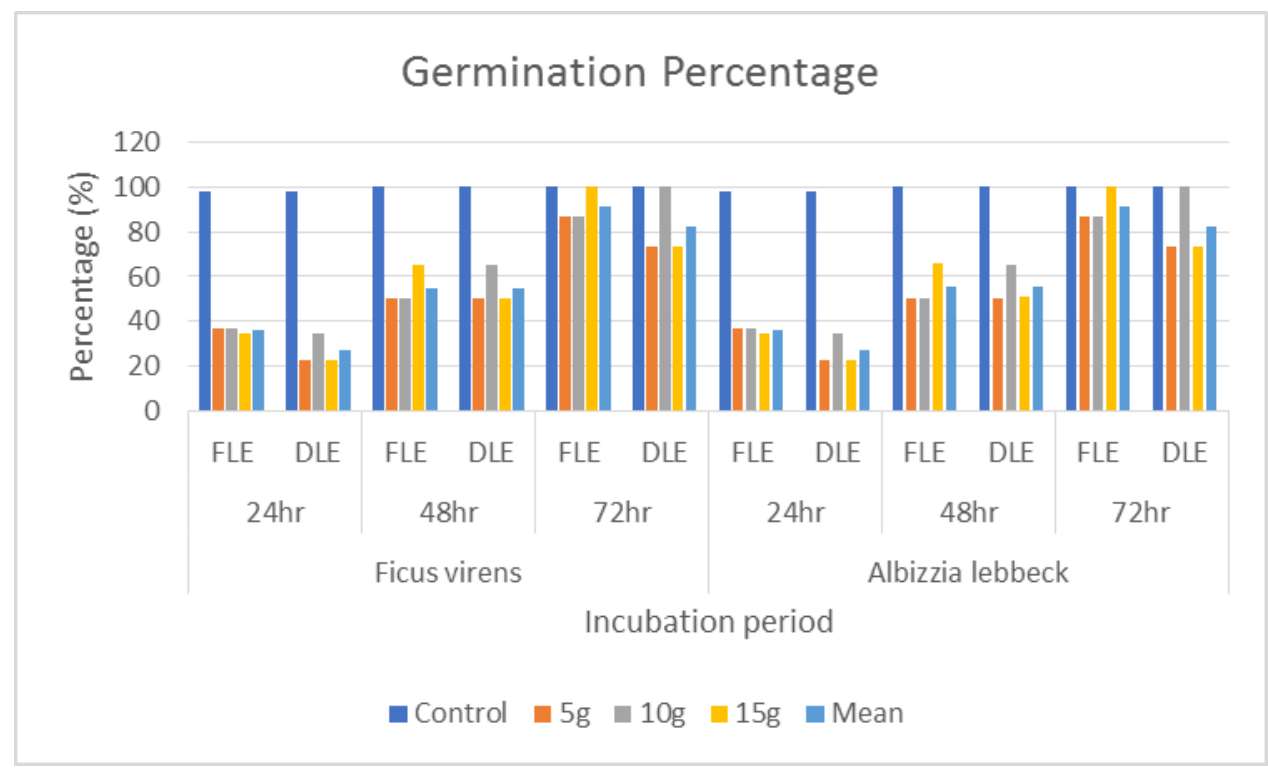

Figure 1. Effect of 24, 48 and 72 hours soaking duration extract of Ficus virens and Albizzia lebbeck at $5 \mathrm{~g}, 10 \mathrm{~g}$ and $15 \mathrm{~g}$ fresh and dry leaves on Germination percentage of Brassica campestris L. FLE = Fresh leaves extract, DLE= Dry leaves extract. Bars represents significance difference at $\mathbf{P}=\mathbf{0 . 0 5}$

Effect of 24, 48 and 72 hours of fresh and dry leaves extract of Albizia lebbeck on Radicle length of Brassica campestris seeds

According to mean values, the maximum radicle length $(1.20,1.02) \mathrm{cm}$ was observed by using both fresh and dry leaves extract separately on Brassica campestris seeds at 72 hours of soaking period followed by $(0.89,0.69) \mathrm{cm}$ at 48 hours of soaking duration and the minimum radicle length was recorded at 24 hours of soaking duration $(0.72,0.42) \mathrm{cm}$ by using dry and fresh extract. More significant inhibitory 
effect was shown by the extract obtained from $10 \mathrm{~g}$ fresh and dry leaves that reduced radicle length to $(0.11 \mathrm{~cm})$ and $(0.17 \mathrm{~cm})$ at $24 \mathrm{hrs}$ of soaking time, followed by $10 \mathrm{~g}$ fresh and $10 \mathrm{~g}$ dry as well as $15 \mathrm{~g}$ dry leaves extract $(0.29 \mathrm{~cm}),(0.3 \mathrm{~cm}), \quad(0.37 \mathrm{~cm})$ at $48 \mathrm{hrs}$ duration. Furthermore it was found out that $5 \mathrm{~g}$ dry and fresh leaves extract have least inhibitory effect i.e. $(2.45 \mathrm{~cm})$ and $(1.04 \mathrm{~cm})$ at 72 hours, $(2.0)$ and $(0.86 \mathrm{~cm})$ at 48 hours, $(1.1 \mathrm{~cm})$ and $(0.54)$ at 24 hours of soaking time as compared to control. So, from the recorded values it is clear that, by increasing extract concentration, inhibitory effect increases (Table 2; Fig. 2).

Effect of 24, 48 and 72 hours of fresh and dry leaves extract of Ficus virens on Radicle length of Brassica campestris seeds

Effect of aqueous extract of Ficus virens L were observed for Brassica campestris seeds and It was found from the mean value of soaking duration that B. Campestris have maximum radicle length $(1.41 \mathrm{~cm})$ and $(0.97 \mathrm{~cm})$ at 72 hours followed by $(1.04 \mathrm{~cm})$ and $(0.75 \mathrm{~cm})$ at 48 hours, $(0.73 \mathrm{~cm})$ and $(0.70 \mathrm{~cm})$ at 24 hours by using fresh and dry extract respectively. Inhibitory effect was observed to increase by increasing the concentration ie extract obtained from $15 \mathrm{~g}$ stands out to be more inhibitory $(0.65 \mathrm{~cm})$ and $(1.23 \mathrm{~cm})$ at 72 hours, $(0.45)$ and $(1.0 \mathrm{~cm})$ at 48 hours, $(0.7 \mathrm{~cm})$ and $(1.0 \mathrm{~cm})$ at 72 hours of soaking duration by using dry and fresh leaves extract separately. At low concentration $(5 \mathrm{~g})$ extract were found to be least inhibitory $(1.25 \mathrm{~cm})$ and $(1.81 \mathrm{~cm})$, followed by $10 \mathrm{~g}$ dry and fresh leaves extract $(0.65 \mathrm{~cm})$ and $(1.23 \mathrm{~cm})$ at 72 hours of soaking duration (Table 2; Fig. 2). The present results are also in line with those of Gulzar [24] observed effect of aqueous extract of Calotropis procera on the growth of Brassica campestris. Their result showed that higher concentration of extract significantly reduced Radicle length and plumule length as compared to control. Same result was also reported by Uniyal and Sachin [25], Hussain and Ilahi [20] also observed allelopathic inhibition of radicle growth of $B$. campestris when different concentration of extracts was applied on its seeds. Similarly, Bahuguna [26] have also revealed that aqueous extract of leaves of walnut significantly reduced Radicle length of $B$. campestris when compared to water control.

Table 2. Effect of 24, 48 and 72 hours soaking duration extract of Ficus virens and Albizzia lebbeck at $5 \mathrm{~g}, 10 \mathrm{~g}$ and $15 \mathrm{~g}$ fresh and dry leaves on Radicle length of Brassica campestris $L$. FLE= Fresh leaves extract, DLE= Dry leaves extract

\begin{tabular}{|c|c|c|c|c|c|c|c|c|c|c|c|c|}
\hline Species & \multicolumn{9}{|c|}{ Ficus virens } & \multicolumn{7}{c|}{ Albizzia lebbeck } \\
\hline $\begin{array}{c}\text { Incubation } \\
\text { period }\end{array}$ & \multicolumn{2}{|c|}{$\mathbf{2 4 h r}$} & \multicolumn{2}{|c|}{$\mathbf{4 8 h r}$} & \multicolumn{2}{|c|}{$\mathbf{7 2 h r}$} & \multicolumn{2}{|c|}{$\mathbf{2 4 h r}$} & \multicolumn{2}{|c|}{$\mathbf{4 8 h r}$} & \multicolumn{2}{c|}{$\mathbf{7 2 h r}$} \\
\hline Treatments & FLE & DLE & FLE & DLE & FLE & DLE & FLE & DLE & FLE & DLE & FLE & DLE \\
\hline Control & 3.98 & 3.98 & 4.15 & 4.15 & 4.38 & 4.38 & 3.98 & 3.98 & 4.15 & 4.15 & 4.38 & 4.38 \\
\hline $5 \mathrm{~g}$ & 1 & 0.69 & 1.31 & 0.99 & 1.81 & 1.25 & 0.54 & 1.1 & 0.86 & 2 & 1.04 & 2.45 \\
\hline $10 \mathrm{~g}$ & 0.5 & 0.41 & 0.8 & 0.81 & 1.19 & 1.02 & 0.11 & 0.17 & 0.29 & 0.37 & 0.59 & 0.67 \\
\hline $15 \mathrm{~g}$ & 0.7 & 1 & 1 & 0.45 & 1.23 & 0.65 & 0.62 & 0.9 & 0.93 & 0.3 & 1.42 & 0.49 \\
\hline Mean & 0.73 & 0.70 & 1.04 & 0.75 & 1.41 & 0.97 & 0.42 & 0.72 & 0.69 & 0.89 & 1.02 & 1.20 \\
\hline
\end{tabular}




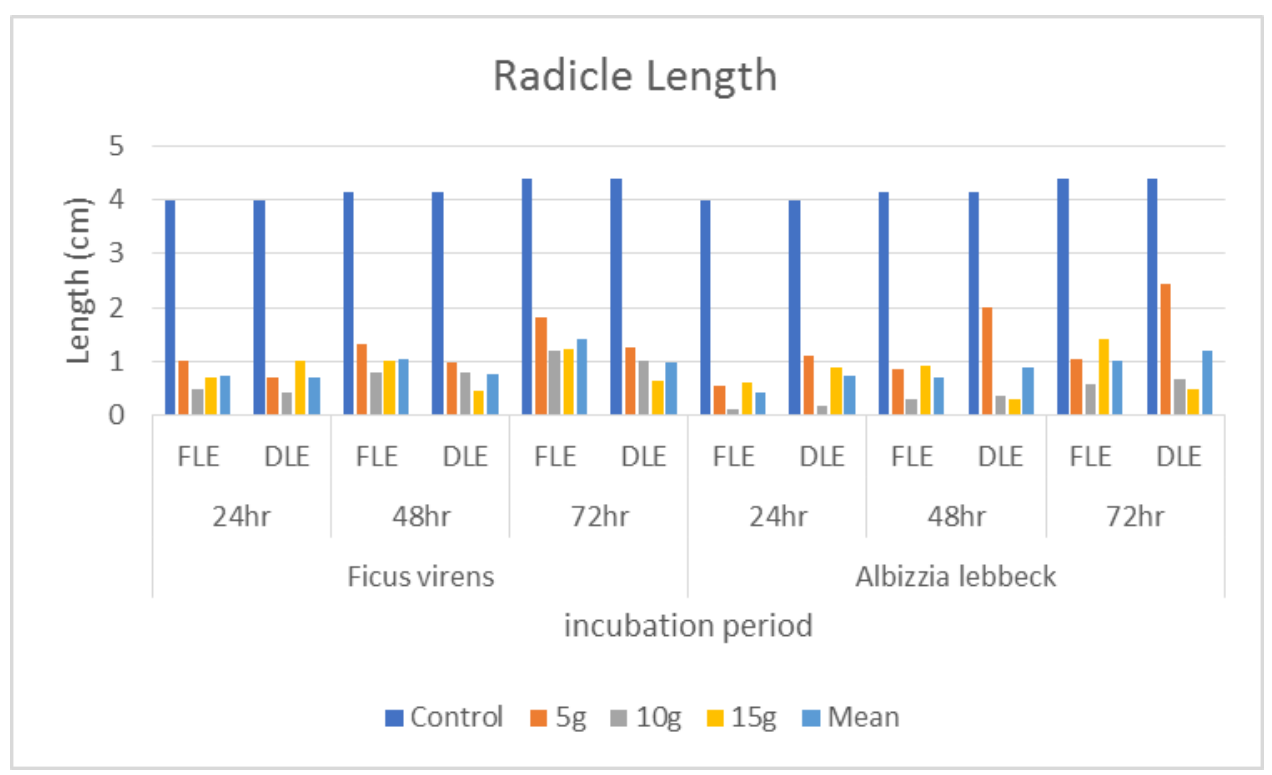

Figure 2. Effect of 24, 48 and 72 hours soaking duration extract of Ficus virens and Albizzia lebbeck at $5 \mathrm{~g}, 10 \mathrm{~g}$ and $15 \mathrm{~g}$ fresh and dry leaves on Radicle length of Brassica campestris $L$. FLE = Fresh leaves extract, DLE $=$ Dry leaves extract. Bars represents significance difference at $P=0.05$.

Effect of 24, 48 and 72 hours of fresh and dry leaves extract of Albizia lebbeck on Plumule length of Brassica campestris seeds

After statistical analysis, plumule length showed varied lengths at different soaking duration. At 24,48 and 72 hours, $0.50 \mathrm{~cm}$ $0.91 \mathrm{~cm}$, and $1.27 \mathrm{~cm}$ plumule lengths were observed by using dry leaves extract. However, for fresh leaves extract at 24, 48 and 72 hours soaking duration $(0.40 \mathrm{~cm})$, $(0.28 \mathrm{~cm})$ and $(0.41 \mathrm{~cm})$ were found. Moreover, extract obtained from $5 \mathrm{~g}$ have least inhibitory effect than $10 \mathrm{~g}$ and $15 \mathrm{~g}$. extract obtained from $5 \mathrm{~g}$ (dry leaves) reduced plumule length to $2.53 \mathrm{~cm}$ while $10 \mathrm{~g}$ and $15 \mathrm{~g}$ reduced plumule length to $0.57 \mathrm{~cm}$ and $0.72 \mathrm{~cm}$ at 72 hours of soaking time. Similarly, $5 \mathrm{~g}$ fresh leaves extract were found to be more inhibitory than $10 \mathrm{~g}$ and $15 \mathrm{~g}$ fresh, $5 \mathrm{~g}$ fresh reduced plumule length to $0.25 \mathrm{~cm}$ while $10 \mathrm{~g}$ and $15 \mathrm{~g}$ reduced plumule length to $0.37 \mathrm{~cm}$ and $0.62 \mathrm{ccm}$ at $72 \mathrm{hrs}$ respectively. Thus, from the result it is clear that with increasing concentration of leaves extract of Albizzia lebbeck L., inhibitory effect was increased (Table 3; Fig. 3).

Effect of 24, 48 and 72 hours of fresh and dry leaves extract of Ficus virens on Plumule length of Brassica campestris seeds

In case of Ficus virens, inhibitory effect was shown by all the extracts for test species with different duration and concentration. At 24, 48 and 72 hours, $0.28 \mathrm{~cm}, \quad 0.50 \mathrm{~cm}$, and $0.79 \mathrm{~cm}$ plumule lengths were observed by using dry leaves extract. However, for fresh leaves extract at 24,48 and 72 hours soaking duration $(0.31 \mathrm{~cm}), \quad(0.57 \mathrm{~cm})$ and $(0.80 \mathrm{~cm})$ were observed. Furthermore, extract obtained from $5 \mathrm{~g}$ have least inhibitory effect than $10 \mathrm{~g}$ and $15 \mathrm{~g}$. 5g (dry leaves) reduced plumule length to $(1.0 \mathrm{~cm})$ while $10 \mathrm{~g}$ and $15 \mathrm{~g}$ reduced plumule length to $0.76 \mathrm{~cm}$ and $0.62 \mathrm{~cm}$ at 72 hours of soaking time. Similarly, $5 \mathrm{~g}$ fresh reduced plumule length 
to $0.9 \mathrm{~cm}$ while $10 \mathrm{~g}$ and $15 \mathrm{~g}$ reduced plumule length to $0.83 \mathrm{~cm}$ and $0.68 \mathrm{ccm}$ at $72 \mathrm{hrs}$ respectively. Same with the case of Albizzia lebbeck L., increasing concentration of leaves extract of Ficus virens, inhibitory effect on test species were increased (Table 3; Fig. 3). These findings correlated with the report of Indergit [27] who found that aqueous extract of leaves of Pluchea lanceolata have inhibitory effect on Brassica Campestris in terms of growth percentage. In such experiment significant reduction in plumule length was observed. Significant reduction in plumule length of
Brassica campestris was also reported by Naveed [28] by studying allelopathic effect of aqueous extract of leaves of Forsskaolea tenacissima on B. campestris. Present results are also in line with those of Ali [29] who concluded that plumule length of Brassica campestris was significantly reduced by aqueous extract of leaves of Diospyros kaki (L.) similarly Gosh [30] have also reported significant reduction of plumule length of $B$. Campestris when leaves extract of Albizzia saman were applied on its seeds.

Table 3. Effect of 24, 48 and 72 hours soaking duration extract of Ficus virens and Albizzia lebbeck at $5 \mathrm{~g}, 10 \mathrm{~g}$ and $15 \mathrm{~g}$ fresh and dry leaves on Plumule length of Brassica campestris $L$. $F L E=$ Fresh leaves extract, $D L E=$ Dry leaves extract

\begin{tabular}{|c|c|c|c|c|c|c|c|c|c|c|c|c|}
\hline Species & \multicolumn{4}{|c|}{ Ficus virens } & \multicolumn{6}{c|}{ Albizzia lebbeck } \\
\hline $\begin{array}{c}\text { Incubation } \\
\text { period }\end{array}$ & \multicolumn{2}{|c|}{$\mathbf{2 4 h r}$} & \multicolumn{2}{|c|}{$\mathbf{4 8 h r}$} & \multicolumn{2}{|c|}{$\mathbf{7 2 h r}$} & \multicolumn{2}{|c|}{$\mathbf{2 4 h r}$} & \multicolumn{2}{|c|}{$\mathbf{4 8 h r}$} & \multicolumn{2}{c|}{$\mathbf{7 2 h r}$} \\
\hline Treatments & FLE & DLE & FLE & DLE & FLE & DLE & FLE & DLE & FLE & DLE & FLE & DLE \\
\hline Control & 1.6 & 1.6 & 2.33 & 2.33 & 2.91 & 2.91 & 1.6 & 1.6 & 2.33 & 2.33 & 2.91 & 2.91 \\
\hline $5 \mathrm{~g}$ & 0.31 & 0.35 & 0.69 & 0.71 & 0.9 & 1 & 0.86 & 1 & 0.18 & 1.7 & 0.25 & 2.53 \\
\hline $10 \mathrm{~g}$ & 0.33 & 0.29 & 0.54 & 0.51 & 0.83 & 0.76 & 0.12 & 0.22 & 0.21 & 0.46 & 0.37 & 0.57 \\
\hline $15 \mathrm{~g}$ & 0.28 & 0.19 & 0.47 & 0.28 & 0.68 & 0.62 & 0.22 & 0.27 & 0.44 & 0.56 & 0.62 & 0.72 \\
\hline Mean & 0.31 & 0.28 & 0.57 & 0.50 & 0.80 & 0.79 & 0.40 & 0.50 & 0.28 & 0.91 & 0.41 & 1.27 \\
\hline
\end{tabular}

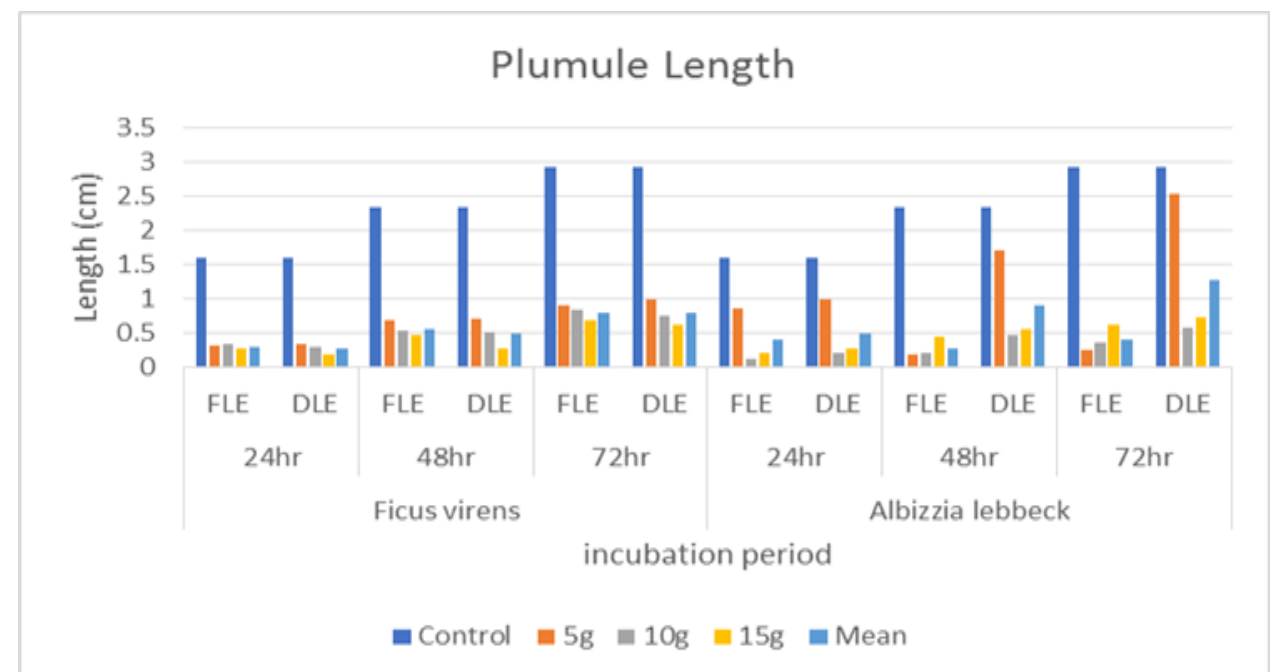

Figure 3. Effect of 24, 48 and 72 hours soaking duration extract of Ficus virens and Albizzia lebbeck at 5g, 10g and 15g fresh and dry leaves on Plumule length of Brassica campestris $L$. $\mathrm{FLE}=$ Fresh leaves extract, DLE= Dry leaves extract. Bars represents significance difference at $\mathbf{P}=\mathbf{0 . 0 5}$. 


\section{Conclusion and Recommendations}

The result of the study concluded that Albizia lebbeck and Ficus virens have some kinds of allelochemicals that could inhibit the germination and seedling growth of mustard crop. Study also indicated that dry leaves extract is more inhibitory on test species than fresh leaves extract, however inhibitory effect of dry leaves extract of Ficus virens is more pronounced on Brassica Campestris than Albizia lebbeck. Plumule length was observed more affected than radicle length, while inhibitory effect of both species on germination percentage of test species was same, at 72 hours of soaking time. It is also investigated that inhibitory effect is concentration and soaking time dependent. The negative effect on test species was increased from 5 to $15 \mathrm{~g}$ treatment, when compared to control. From the observations and the results, it is concluded that Albizia lebbeck and Ficus virens as significant allelopathic potential reduced the radicle and plumule growth as well as the germination percentage of Brassica campestris as compared to control. The current data provided evidences that allelochemicals might be present in leaves extract of $F$. virens and A. lebbeck that are involved in the suppression of $B$. campestris germination and growth. Therefore A. lebbeck and F. Virens should not be cultivated near the $B$. campestris field. It is also recommended that Albizia lebbeck and Ficus virens can be utilized in weed management in future, if properly studied for its chemicals that are responsible for suppression of Brassica campestris. As Brassica campestris is economically very important, therefore further studies should be done in order to find out in which environment and habitat it can grow best and not affect other plants and vice versa.

\section{Authors' contributions}

Conceived and designed the experiments: S Khalid \& U Ibrahim, Performed the experiments: U Ibrahim, S Riaz, WM Khan and R Kausar, Analyzed the data: M Naseem, R Kausar, SIU Haq \& M Sajjad, Contributed materials/analysis/ tools: S Khalid, WM Khan, Wrote the paper: S Khalid, U Ibrahim, S Riaz, SIU Haq.

\section{References}

1. Anonymous (1996). (International Allelopathic Society). First world congress on Allelopathy. A science for the future, Cadiz, Spain.

2. Cornes D (2005). Callisto: A very successful maize herbicide inspired by allelochemistry. In proceedings of the Fourth World Congress on Allelopathy 2(7): 2630.

3. Khalaj MA, Amiri $M$ \& Azimi $\mathrm{MH}$ (2013). Allelopathy: Physiological, and Sustainable agriculture important aspects. Int J Agron Plant Prod 4(5): 950-962.

4. Rice EL (1984). Allelopathy, $2^{\text {nd }}$ edition. Academic press, New York U.S.A. pp.422.

5. Brooks AM (2008). "Allelopathy in Rye (secale cereal)". Crop Sci 67-1466-08.

6. Csiszar A (2009). Allelopathic effects of Invasive woody plant species in Hungary. Acta sylvatica et Lignaria Hungary 5: 917.

7. Fasciola S (1998). The second addition of an excellent guide to the edible uses of plants. Kanpong Publications, California. Cornucopia II. ISBN: 0-9628087-2-5.

8. Mansfeld's Database of Agricultural and Horticultural Plants (MDAHP). Terse details of a huge range of useful plants.

9. Chopra RN, Nayar SL \& Chopra IC (1986). Glossary of Indian Medicinal Plants (Including the supplements). Council of Scientific and Industrial Research. New Delhi.

10. Clarke WC \& Thaman RR (1993). United Nation University Press, Tokyo.

11. Beentje HJ (2002). Flora of Tropical East Africa, Royal Botanic Gardens, Kew.

12. Flora of Pakistan. http://www.efloras.org. As of 2006, there is not much information on habitat available, but it is being developed and promises to be an excellent resource.

13. Mamun AN, Matin MN, Bar MA, Siddique NA, Sultan RS, Rahman MH \& 
Musa AS (2004). Micro propagation of weedy legume Albizia lebbeck through tissue culture. Pak J Biol Sci 7: 10991103.

14. Shrisha K, Priyanka B, Rahman B \& Ali D (2013). Review on Albizia lebbeck (L.) Benth: A plant Possessing Diverse Pharmacological Activities. Res J Pharmacog Phytochem 5: 263-268.

15. Paula RCN, Santana SA \& Rodrigues JF (2001). Composition and rheological properties of Albizia lebbeck gum exudate. Carbohydr Polym 44: 133-139.

16. Rahul C, Pankaj P, Sarwan KS \& Mahesh JK (2010). Phytochemical screening and antimicrobial activity of Albizzia lebbeck. J Chem Pharm Res 2(5): 476-484.

17. Thomas J, Kuruvilla KM \& Hrideek TK (2004). Mustard. J Exp Bot 54(5)196-205.

18. Scott DB, Mudie PJ, Vilks G \& Younger DC (1984). Latest Pleistocene-Holocene paleoceanographic trends on the continental margin of eastern Canada: foraminiferal, dinoflagellate and pollen evidence. Mar Micropaleontol 9: 181218.

19. Barkatullah, F, Hussain F \& Ibrar M (2010). Allelopathic potential of Dodonaea viscosa (L.) Jacq. Pak J Bot 42(4): 2383-2390.

20. Hussain F, Ahmad B \& Ilahi I (2010). Allelopathic effects of Cenchrus ciliaris L. and Bothriochloa pertusa (L.) A. Camus. Pak J Bot 42(5): 3587-3604.

21. Samreen U, Hussain F \& Sheraz M (2009). Allelopathic potential of Calotropis procera (Ait). Pak J Bot 15: 714.

22. Antony S \& Beny PJ (2018). Allelopathic effect of Flacourita Inermis on seed germination of selected crop plants found in India. Int $J$ of adv in Sci Eng Technol (IJASEAT) 4(4): 56-58.
23. Maharajan S, Shreshta BB \& Jha PK (2007). Allelopathic effect of leaves of Parthenium hysterophorus L. on seed germination and seedling growth of some cultivated and wild herbaceous species. Sci World J 5: 31-33.

24. Gulzar A \& Siddiqui MB (2017). Allelopathic effect of calotropis procera on growth and antioxidant activity of Brassica campestris. J Saudi Soc Agric 16(4): 375-382.

25. Uniyal A \& Chhetri KS (2010). An assessment of phytotoxic potential of promising Agroforestry treeson Germination and growth pattern of Traditional field crops of Sikkim Himalaya, India. American-Europe. $J$ Agric Enviro Sci 9(1): 70-78.

26. Bahuguna S, Bahuguna A \& Singh N (2014). Allelopathic Belongings of Dried walnut leaf on seed germination and seedling Growth of Mustard (B. campestris) in Agri- Silvi system of Uttara Khand Himalaya, India. Am J Food Technol 9(3): 172-179.

27. Indergit (2008). Allelopathic effect of Pluchea lanceolata on growth and yield components of mustard (Brassica juncea) and its influence on selected soil properties. Weed biol Manag 2: 200-204.

28. Naveed S, Hussain F, Khattak I, Khan K \& Barkatullah (2012). Allelopathic Potential of Forsskaolea tenacissima. Int J Med App Sci 1(1): 4756.

29. Ali N, Ibrar M, Barkatullah \& Ahmad I (2011). Allelopathic potential of Diospyros kaki L. against Triticum aestivum L., Brassica compestris L. and Trifolium alexandrinum L. J Bio Enviro Sci (JBES) 1(5): 57-65.

30. Ghosh S, Molla KA \& Ghosh K (2013). Allelopathic effect of Albizia saman F. Muell on three widely cultivated Indian crop species. J Agric Vet Sci 5(3): 13-18. 